\title{
Pola Hidup Sehat Dengan Olahraga dan Asupan Gizi Untuk Meningkatkan Imun Tubuh Menghadapi Covid-19
}

\author{
Yahya Eko Nopiyanto ${ }^{1}$, Septian Raibowo ${ }^{2}$, Tono Sugihartono ${ }^{3}$, \\ Yarmani $^{4}$ \\ ${ }_{1,2,3,4}$ Pendidikan Jasmani, Universitas Bengkulu \\ E-mail:yahyaekonopiyanto@unib.ac.id
}

\begin{tabular}{ll}
\hline Article History: & Abstrak: \\
Received: Oktober & Pengabdian masyarakat dilaksanakan di desa \\
Revised: November & Suku Menanti, Kabupaten Rejang Lebong \\
Accepted: November & pada tanggal 5-6 September 2020. Mitra \\
Available online: Desember & dalam pengabdian ini adalah pemuda karang \\
& taruna di desa IV Suku Menanti yang \\
& berjumlah 25 orang. Tujuan pengabdian ini \\
Kata Kunci: asupan & adalah untuk memberikan pengertian, \\
gizi, imun tubuh, karang & pemahaman, dan cara melakukan pola hidup \\
taruna, sosialisasi. & sehat dengan olahraga dan asupan gizi untuk \\
& meningkatkan imun tubuh menghadapi covid- \\
& 19. Bentuk kegiatan yang dilakukan adalah \\
& sosialisasi dengan model ceramah dan small \\
& group discussion. Tahapan yang dilakukan \\
& adalah perkenalan, sosialisasi, dan evaluasi. \\
& Hasil evaluasi kegiatan dapat disimpulkan \\
& bahwa kegiatan ini dapat meningkatkan \\
pemahaman dan keterampilan mitra di Suku \\
Menanti, Kabupaten Rejang Lebong \\
mengenai pola hidup sehat dengan olahraga \\
dan asupan gizi untuk meningkatkan imun \\
tubuh menghadapi covid-19.
\end{tabular}

\section{Pendahuluan}

Penyakit pernapasan akut yang disebabkan oleh coronavirus baru (SARS-CoV-2, yang sebelumnya dikenal sebagai 2019-nCoV), penyakit corona virus 2019 (Covid-19) telah menyebar ke seluruh Tiongkok dan mendapat perhatian dunia. Pada 30 Januari 2020, Kesehatan Dunia Organisasi 
(WHO) secara resmi menyatakan epidemi Covid-19 sebagai darurat kesehatan masyarakat yang menjadi perhatian internasional. Virus corona atau Covid-19 adalah kumpulan virus yang bisa menginfeksi sistem pernapasan manusia. Banyak dampak negatif yang disebabkan oleh virus ini, diantaranya adalah infeksi pernapasan ringan maupun berat, seperti pneumonia (infeksi paruparu), midlde east respiratory syndrome (MERS), dan severe acute respiratory syndrome (SARS). Gejala awal untuk mengetahui bahwa seseorang mengalami infeksi virus ini adalah flu, sesak napas, nyeri di bagian dada, batuk berdahak ataupun berdarah, demam, sakit kepala. Gejala-gejala tersebut muncul ketika tubuh bereaksi melawan virus Corona (Guo et al, 2020).

Berdasarkan hasil penelitian yang telah dilakukan menunjukkan bahwa virus Covid-19 ditransmisikan selama kontak dekat melalui tetesan pernapasan (seperti batuk) dan oleh hubungan jarak dekat (Liu et al, 2020). Virus dapat menyebar langsung dari manusia ke manusia ketika penderita Covid-19 batuk atau buang nafas menghasilkan tetesan yang mencapai hidung, mulut atau mata orang lain. Atau, karena tetesan terlalu berat untuk di udara, mereka mendarat di benda dan permukaan yang mengelilingi orang tersebut. Orang lain juga dapat terinfeksi Covid-19 dengan menyentuh benda atau permukaan yang terkontaminasi ini kemudian menyentuh mata, hidung atau mulut mereka. Berdasarkan hasil penelitian juga menyatakan bahwa penularan melalui udara pada jarak satu meter, jumlahnya sedikit jika dibandingkan dengan kontak langsung dengan penderita.

WHO terus merekomendasikan agar setiap orang melakukan kebersihan tangan secara teratur, menggunakan masker, dan membersihkan benda yang ada di sekitar dengan menggunakan disinfektan secara teratur. WHO juga terus merekomendasikan pentingnya menjaga jarak fisik dan menghindari orang dengan gejala pernapasan atau demam. Tindakan pencegahan ini akan membatasi penularan virus (WHO, 2020). Selain itu untuk mencegah penularan virus covid 19 maka diperlukan pola perilaku hidup bersih dan sehat (Karo, 2020). Pola perilaku hidup bersih dan sehat dapat dimulai dengan melakukan olahraga teratur dan menjaga asupan gizi untuk menjaga dan meningkatkan sistem imun tubuh dalam menghadapi 
covid-19.

Berdasarkan hasil penelitian dapat diketahui bahwa olahraga rutin dapat meningkatkan imunitas tubuh, sehingga berperan dalam pencegahan infeksi covid-19 (Tiksnadi, dkk, 2020). Selain itu asupan gizi yang tepat juga dapat membantu untuk pencehagan infeksi covid-19 (Prawiradilaga, 2020). Namun, tidak semua pihak mengetahui bagaimana cara memulai dan menjaga pola hidup sehat dengan olahraga dan asupan gizi untuk meningkatkan imun tubuh menghadapi covid-19, khususnya di desa Suku Menanti Kabupaten Rejang Lebong

Masalah-masalah yang dihadapi warga masyarakat di desa Suku Menanti Kabupaten Rejang Lebong pada masa pandemi covid-19 diantaranya adalah belum mendapatkan informasi mengenai pola hidup sehat di masa pandemi covid-19, belum mengetahui cara berolahraga yang baik di masa pandemi covid-19, belum mendapatkan informasi mengenai asupan gizi yang tepat sebagai upaya pencegahan covid-19. Permasalahan-permasalahan tersebut harus segera mendapatkan penanganan serius. Namun, hingga saat ini tindakan yang dilakukan oleh pihak terkait dalam menangani masalahmasalah tersebut belum optimal, terlebih lagi mengenai pola hidup sehat dengan olahraga dan asupan gizi untuk meningkatkan imun tubuh menghadapi covid-19. Sebagai upaya konkrit dalam memberikan pengetahuan dan keterampilan bagi warga masyarakat di desa Suku Menanti dalam menghadapi covid-19 adalah dengan melakukan sosialisasi pola hidup sehat dengan olahraga dan asupan gizi untuk meningkatkan imun tubuh menghadapi covid-19.

\section{Metode}

Desa IV Suku Menanti, Sidang Dataran, Kabupaten Rejang Lebong, Provinsi Bengkulu menjadi tempat pelaksanaan kegiatan pengabdian ini. Mitra dalam pengabdian ini adalah pemuda karang taruna di desa IV Suku Menanti yang berjumlah 25 orang. Kegiatan ini dilaksanakan pada tanggal 56 September 2020. Bahan-bahan yang dibutuhkan dalam pertemuan dengan para mitra berupa laptop, LCD, slide power point, speaker/sound system. 
Bentuk kegiatan yang dilakukan adalah sosialisasi. Kegiatan ini dilakukan dengan model ceramah dan small group discussion. Tahapan yang dilakukan pada kegiatan ini terdiri dari tiga tahapan, yaitu:

1. Tahap pertama adalah perkenalan. Tahap ini dilakukan bertujuan untuk mengenalkan masing-masing tim pengabdian dan mitra dalam kegiatan ini. Sehingga dengan saling mengenal satu sama lain diharapkan kegiatan pengabdian masyarakat ini dapat berjalan dengan baik.

2. Tahap kedua adalah sosialisasi. Tahap ini dilakukan bertujuan untuk memberikan pengertian, pengetahuan dan pemahaman tentang pola hidup sehat dengan olahraga dan asupan gizi untuk meningkatkan imun tubuh menghadapi covid-19.

3. Tahap ketiga adalah evaluasi. Tahap ini dilaksanakan untuk mengevaluasi jalannya kegiatan. Evaluasi dilaksanakan dengan menggunakan data angket yang diberikan kepada mitra pada awal mengikuti kegiatan ini dan angket yang diberikan pada akhir kegiatan ini. Evaluasi dilakukan dengan membandingkan nilai peserta sebelum dan sesudah kegiatan dilaksanakan.

\section{Hasil}

Kegiatan ini menghasilkan peningkatan pengetahuan dan keterampilan bagi mitra tentang melakukan pola hidup sehat dengan olahraga dan asupan gizi untuk meningkatkan imun tubuh menghadapi covid-19. Pengetahuan yang diberikan pada kegiatan ini adalah, (1) mencuci tangan dengan bersih, (2) mengkonsumsi makanan yang bergizi, (3) menjaga kebersihan lingkungan, (4) melakukan olahraga secara teratur, (5) mengatur waktu istirahat dengan baik. Hasil kegiatan ini dapat dilihat pada gambar 1 di bawah ini.

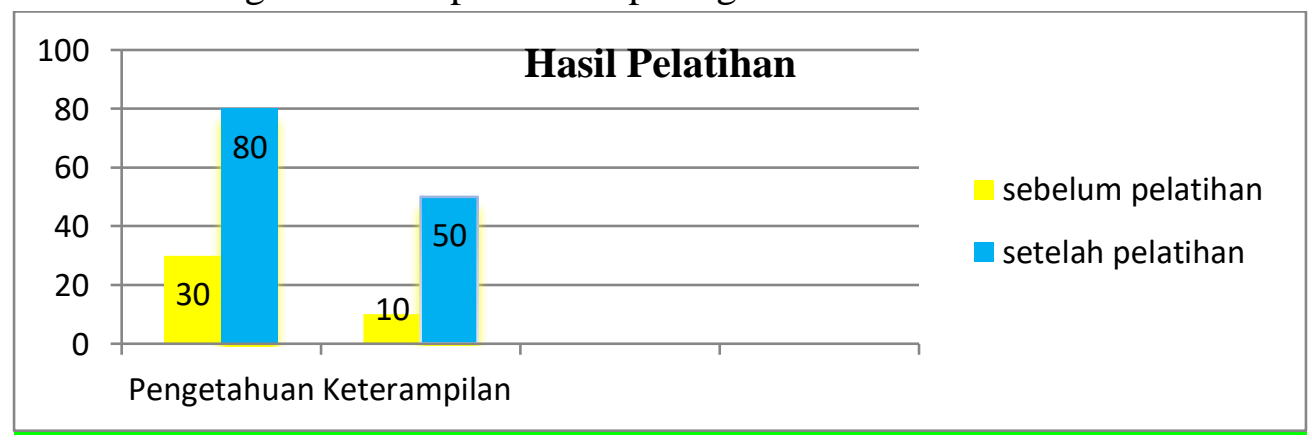

Gambar 1. Pengetahuan dan keterampilan peserta sebelum dan sesudah kegiatan 
Berdasarkan pada gambar 1 dapat diketahui bahwa tingkat pengetahuan mitra mengenai pola hidup sehat dengan olahraga dan asupan gizi untuk meningkatkan imun tubuh menghadapi covid-19 sebanyak 30\%, dan keterampilan mitra dalam melakukan pola hidup sehat dengan olahraga sebanyak 10\%. Namun, setelah diadakan pelatihan oleh tim pengabdi pengetahuan dan keterampilan mitra mengalami peningkatan. Tingkat pengetahuan mitra meningkat menjadi $80 \%$, dan tingkat keterampilan mitra meningkat menjadi 50\%. Pengetahuan dan keterampilan yang diberikan pada kegiatan ini dapat berjalan dengan baik melalui tiga tahapan sebagai berikut:

\section{Tahap Perkenalan}

Tahap perkenalan dipimpin oleh kepala desa, lalu dilanjutkan oleh anggota tim pengabdi. Pada tahap ini masing-masing anggota tim pengabdian memperkenalkan diri dihadapan para mitra yang menjadi peserta kegiatan.Setelah anggota tim pengabdian memperkenalkan diri, maka dilanjutkan oleh para peserta kegiatan. Tidak lupa juga, tim pengabdi menjelaskan maksud dan tujuan diadakan kegiatan ini. Dengan saling mengenal satu sama lain dan mengetahui tujuan dari kegiatan maka diharapkan kegiatan pengabdian masyarakat ini dapat berjalan dengan baik.

Tahap perkenalan dilaksanakan pada pukul 09.00-10.00 WIB tanggal 5 September 2020. Proses perkenalan berlangsung selama 60 menit. Pada tahap ini juga tim pengabdi mengajukan beberapa pertanyaan tentang pola hidup sehat dan asupan gizi yang cukup untuk menjaga daya tahan imun tubuh. Namun, sebagian besar peserta belum mengetahui jawaban dari pertanyaan yang diajukan oleh tim pengabdi. Untuk mengetahui tingkat pemahaman peserta maka tim pengabdi membagikan angket sebagai bahan untuk evaluasi kegiatan.

\section{Tahap Sosialisasi}

Tahap sosialisasi dibagi menjadi dua sesi. Pembagian sesi bertujuan untuk memfokuskan materi yang akan disampaikan kepada semua peserta. Sesi pertama adalah sosialisasi mengenai pola hidup sehat dan asupan gizi yang seimbang sebagai upaya pencegahan Covid-19. Sesi pertama dimulai pada pukul 10.00-12.00 WIB. Materi yang disampaikan pada sesi pertama terdiri dari: 1) pengertian pola hidup sehat, 2) tujuan dan manfaat pola hidup sehat, 3) cara menjalani pola hidup sehat. Sebelum menyampaikan materi, tim 
pengabdi menanyakan pertanyaan sederhana kepada peserta untuk mengetahui tingkat pemahaman awal sebelum memulai materi. Penyampaian materi pada sesi pertama menggunakan metode ceramah yang disampaikan oleh tim pengabdi. Dalam penyampaiannya tim pengabdi menggunakan media atau alat bantu seperti laptop, LCD, sound system yang bertujuan supaya peserta mudah memahami materi yang disampaikan. Pada pukul 13.00 WIB sesi pertama dilanjutkan kembali dengan metode small group discussion. Peserta dibagi menjadi kelompok kecil yang terdiri dari 5 orang untuk mendiskusikan tujuan dan manfaat pola hidup sehat serta cara menjalani pola hidup sehat. Peserta diberikan waktu selama 45 menit untuk melakukan diskusi mengenai topik yang diberikan. Setelah itu, masing-masing perwakilan dari kelompok menampilkan hasil diskusinya di depan kelompok lain. Sementara itu kelompok lain menanggapi hasil diskusi kelompok yang tampil. Diskusi berjalan dengan baik dan semua peserta sangat antusias dalam mengikuti jalannya diskusi hingga berakhir pada pukul 14.30 WIB. Pada akhir sesi pertama tim pengabdi dan semua peserta secara bersama-sama merangkum dan menyimpulkan materi yang disampaikan dan diakhiri dengan evaluasi. Penyampaian materi sesi pertama berakhir pada pukul 15.00 WIB, dan akan dilanjutkan pada sosialisasi sesi 2 pada tanggal 6 September 2020.

Tahap sosialisasi sesi kedua dimulai pada pukul 09.00-12.00 WIB tanggal 6 September 2020. Materi yang disampaikan pada sesi kedua adalah olahraga yang aman di masa pandemi Covid-19 yang terdiri dari: 1) jenis-jenis olahraga yang baik di masa pandemi, 2) manfaat olahraga di masa pandemi, 3) tips melakukan olahraga di masa pandemi, 4) kesalahan-kesalahan dalam melakukan olahraga di masa pendemi. Penyampaian materi pada sesi kedua menggunakan metode ceramah yang disampaikan oleh tim pengabdi. Dalam penyampaiannya tim pengabdi menggunakan media atau alat bantu seperti laptop, LCD, sound system yang bertujuan supaya peserta mudah memahami materi yang disampaikan. Pada pukul 13.00 WIB sesi pertama dilanjutkan kembali dengan metode small group discussion. Peserta dibagi menjadi kelompok kecil yang terdiri dari 5 orang untuk mendiskusikan tujuan dan manfaat pola hidup sehat serta cara menjalani pola hidup sehat. Peserta diberikan waktu selama 45 menit untuk melakukan diskusi mengenai topik yang diberikan. Setelah itu, masing-masing perwakilan dari kelompok 
menampilkan hasil diskusinya di depan kelompok lain. Sementara itu kelompok lain menanggapi hasil diskusi kelompok yang tampil. Diskusi berjalan dengan baik dan semua peserta sangat antusias dalam mengikuti jalannya diskusi hingga berakhir pada pukul 14.30 WIB. Pada akhir sesi kedua tim pengabdi dan semua peserta secara bersama-sama merangkum dan menyimpulkan materi yang disampaikan dan diakhiri dengan evaluasi. Penyampaian materi sesi kedua berakhir pada pukul 15.00 WIB. Pada akhir kegiatan, tim pengabdi membagikan angket kepada semua peserta untuk mengetahui perbedaan pemahaman tentang pola hidup sehat dengan olahraga dan asupan gizi untuk meningkatkan imun tubuh menghadapi covid-19 sebelum dan sesudah mengikuti kegiatan ini.

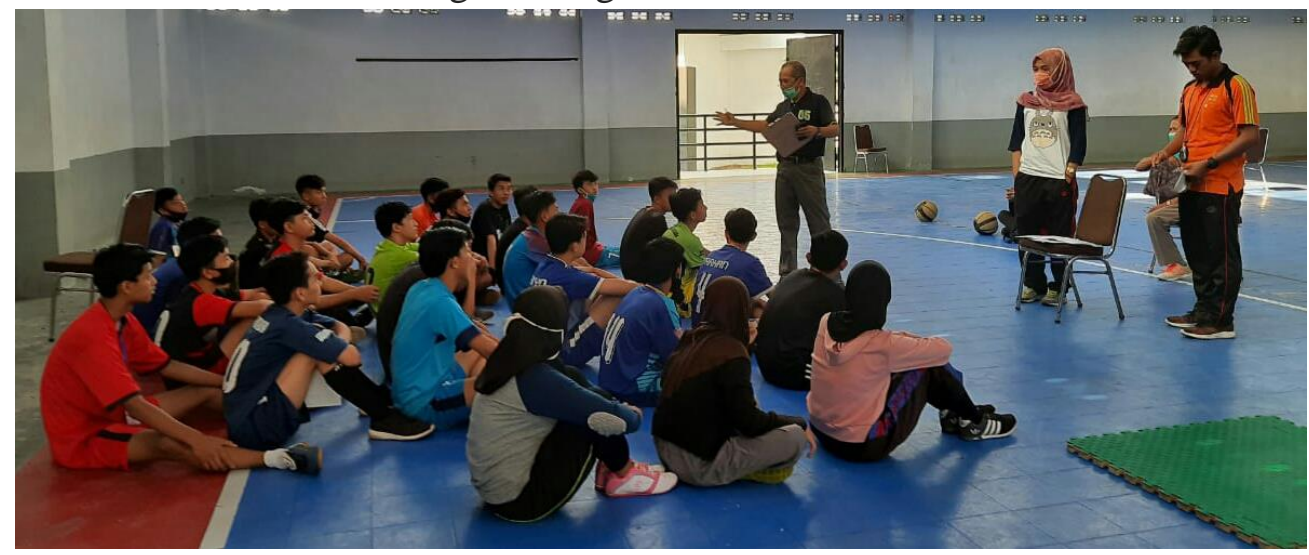

Gambar 2. Tim Peneliti Memberikan Materi Olahraga di Masa Pandemi Covid

\section{Tahap Evaluasi}

Pada tahap akhir kegiatan, tim pengabdi melakukan evaluasi yang bertujuan untuk mengetahui keberhasilan dari kegiatan ini dalam meningkatkan pengetahuan dan keterampilan peserta tentang pola hidup sehat dengan olahraga dan asupan gizi untuk meningkatkan imun tubuh menghadapi covid-19. Evaluasi dilakukan dengan cara menganalisis hasil pengamatan dan data dari angket yang diberikan kepada semua peserta kegiatan ini. Hasil evaluasi dapat dilihat pada tabel 1 di bawah ini. 
Tabel. 1 Hasil Evaluasi Kegiatan

\begin{tabular}{ccc}
\hline \multirow{2}{*}{ Indikator } & \multicolumn{2}{c}{ Hasil Evaluasi } \\
\cline { 2 - 3 } & Pre-test & Post-test \\
\hline Pengetahuan & $30 \%$ & $80 \%$ \\
\hline Keterampilan & $10 \%$ & $50 \%$ \\
\hline
\end{tabular}

Berdasarkan data hasil evaluasi kegiatan pada tabel 1, dapat diketahui bahwa hasil kegiatan ini memberikan dampak positif yang signifikan terhadap peningkatan pengetahuan dan keterampilan peserta mengenai pola hidup sehat dengan olahraga dan asupan gizi yang seimbang dalam menjaga dan meningkatkan imun tubuh menghadapi covid-19. Pada indikator pengetahuan terdapat peningkatan $50 \%$, artinya ada perbedaan yang signifikan antara sebelum dan setelah diadakan kegiatan. Peningkatan pengetahuan mitra setelah mengikuti pelatihan ini tidak terlepas dari metode pelaksanaan pengabdian, yaitu menggunakan small group discussion dan cooperative learning. Berdasarkan hasil penelitian diketahui bahwa metode cooperative learning dapat meningkatkan hasil belajar (Nopiyanto \& Raibowo, 2020). Dengan adanya peningkatan pemahaman mitra mengenai asupan gizi yang seimbang diharapkan akan meningkatkan produktivitas kerja mitra. Sebagaimana yang diketahui bahwa status kesehatan dan kebugaran seseorang dipengaruhi oleh gizi seimbang (Torres-McGehee et al., 2012). Selain itu, volume oksigen maksimal mampu ditingkatkan dengan pemberian asupan gizi yang seimbang (Sirajuddin, 2016).

Pada indikator keterampilan terdapat peningkatan $40 \%$, artinya ada perbedaan yang signifikan antara sebelum dan setelah diadakan kegiatan. Hal ini dapat terjadi karena selama kegiatan berlangsung, tim pengabdi memberikan materi dengan jelas, mudah dipahami, dan dilengkapi dengan video dan demonstrasi. Selain itu juga, semua peserta sangat antusias dan termotivasi dalam mengikuti kegiatan ini. Motivasi berolahraga mempunyai hubungan yang signifikan dengan prestasi seseorang dalam melakukan olahraga (Nopiyanto \& Dimyati, 2018; Nopiyanto, Dimyati, \& Dongoran, 2019). Selain itu, proses pengabdian yang dilakukan secara sistematis, menggunakan bentuk pelatihan dan pendampingan dapat meningkatkan pengetahuan dan keterampilan mitra pengabdian (Nopiyanto \& Raibowo, 
2020). Dengan meningkatnya keterampilan dalam melakukan olahraga diharapkan mitra mampu melakukan olahraga yang diminatinya sehingga dapat meningkatkan imun tubuh dalam menghadapi covid-19. Beberapa jenis olahraga yang disarankan juga dapat dimodifikasi bentuk dan peraturannya sehingga mempermudah pelaksanaannya dan mempunnyai hasil yang signifikan (Pujianto et al, 2020). Sebagaimana yang diketahui bahwa olahraga dengan intesitas ringan sampai sedang yag dilakukan secara rutin dapat meningkatkan imun tubuh (Hadi, 2020). Selain sangat dianjurkan untuk berolahraga yang tidak dilakukan secara massal, menghindari kerumunan, menjaga jarak dan dilakukan dengan intensitas ringan sampai sedang guna menjaga imun tubuh dalam menghadapi covid-19 (Wijayanto, 2020).

\section{Kesimpulan}

Berdasarkan pada hasil evaluasi kegiatan dapat disimpulkan bahwa kegiatan ini dapat meningkatkan pemahaman dan keterampilan mitra di Suku Menanti, Kabupaten Rejang Lebong mengenai pola hidup sehat dengan olahraga dan asupan gizi untuk meningkatkan imun tubuh menghadapi covid19.

\section{Acknowledgements}

Tim pengabdian mengucapkan terimakasih kepada Lembaga Penelitian dan Pengabdian Kepada Masyarakat (LPPM) Universitas Bengkulu yang telah memberikan izin kegiatan ini. Dan tim pengabdian mengucapkan terimakasih kepada semua pihak yang terlibat yaitu mitra pengabdian Karan Taruna di Desa IV Suku Menanti dan Kepala Desa IV Suku Menanti beserta peragkat desa lainnya. Semoga dengan adanya kegiatan pengabdian yang dilakukan ini memberikan dampak positif dan perkembangan yang lebih baik kedepannya bagi warga Desa IV Suku Menanti.

\section{Daftar Referensi}

Guo et al. (2020). The origin, transmission and cinical therapies on coronavirus disease 2019 (COVID-19) outbreak - an update on the status. Military Medical Research . 7:11. doi.org/10.1186/s40779-02000240-0.

Hadi, F. K. (2020). Aktivitas Olahraga Bersepeda Masyarakat Di Kabupaten 
Malang Pada Masa Pandemi Covid-19. Sport Science and Education Journal, 1(2), 28-36.

Karo, M. B. (2020). Perilaku Hidup Bersih dan Sehat (PHBS) Strategi Pencegahan Penyebaran Virus Covid-19. In Prosiding Seminar Nasional Hardiknas (Vol. 1, pp. 1-4).

Liu J, Liao X, Qian S et al (2020). Community transmission of severe acute respiratory syndrome coronavirus 2, Shenzhen, China. Emerg Infect Dis 2020 doi.org/10.3201/eid2606.200239.

Nopiyanto, Y. E., \& Dimyati, D. (2018). Karakteristik psikologis atlet Sea

Games Indonesia ditinjau dari jenis cabang olahraga dan jenis kelamin. Jurnal Keolahragaan, 6(1), 69-76.

Nopiyanto, Y. E., Dimyati, D., \& Dongoran, F. (2019). Karakteristik Psikologis Atlet Sea Games Indonesia Ditinjau Dari Cabang Olahraga Tim. Sporta Saintika, 4(2), 27-46.

Nopiyanto, Y. E., \& Raibowo, S. (2020). Pelatihan Olahraga Futsal sebagai

Sarana Mengurangi Aktivitas Game Online pada Anak-Anak di

Kelurahan Mangunharjo. JURPIKAT (Jurnal Pengabdian Kepada Masyarakat), 1(2), 67-77.

Nopiyanto, Y. E., \& Raibowo, S. (2020). Penerapan model pembelajaran Jigsaw untuk meningkatkan motivasi dan hasil belajar mahasiswa penjas pada mata kuliah filsafat penjas dan olahraga. Journal Of Sport Education (JOPE), 2(2), 61-69.

Prawiradilaga, R. S. (2020). COVID-19 dan tatalaksana gizi. Pusat Penerbitan Unisba (P2U) LPPM UNISBA.

Pujianto, D., Sutisyana, A., Arwin, A., \& Nopiyanto, Y. E. (2020).

Pengembangan Model Latihan Passing Sepakbola Berbasis Sasaran

Teman. Journal Coaching Education Sports, 1(1), 1-12.

Sirajuddin. (2016). Pengaruh Intervensi Gizi Olah Raga Terhadap Kadar

Kholesterol, Asupan Karbohidrat, Protein, Lemak Dan Volume Oksigen (VO2) Maksimum Usia Dewasa. Media Kesehatan Politeknik Kesehatan Makassar, XI(2), 9-20.

Tiksnadi, B. B., Sylviana, N., Cahyadi, A. I., \& Undarsa, A. C. (2020). Olahraga Rutin Untuk Meningkatkan Imunitas Pasien Hipertensi

Selama Masa Pandemi COVID-19. Indonesian Journal of Cardiology, 41(2), 113-9.

Torres-McGehee, T. M., Pritchett, K. L., Zippel, D., Minton, D. M., Cellamare, A., \& Sibilia, M. (2012). Sports nutrition knowledge among collegiate athletes, coaches, athletic trainers, and strength and conditioning specialists. Journal of Athletic Training, 47(2), 205-211. 
https://doi.org/10.4085/1062-6050-47.2.205

WHO Infection Prevention and Control Guidance for COVID-19 available at https://www.who.int/emergencies/diseases/novel-coronavirus2019/technical-guidance/infection-prevention-and control.

Wijayanto. (2020). Jaga Jarak Fisik, Jaga Kesehatan, Jaga Kebugaran Untuk Meningkatkan Imunitas Tubuh Di Tengah Gempuran Covid19.Tulungagung: Akademia Pustaka. 